\title{
"IF I FORGET THEE, O BAGHDAD": THE DEMISE OF ARAB-JEWISH IDENTITY AND CULTURE
}

\author{
Reuven SNIR \\ The University of Haifa \\ 199 Aba Khoushy Ave. Mount Carmel, Haifa, 3498838, Israel \\ rsnir@univ.haifa.ac.il
}

This article examines the emergence of the modern Arabic literary writing of the Jews of Iraq and, after only a few decades, the start of its demise, in both Iraq and outside it, and then the switch to writing in Hebrew in Israel. The high point of such writing in Arabic was during the 1920 s when Iraqi-Jews started to produce literary works that "were Arabic in essence and expression." It was a secular literature, inspired by a cultural vision whose most eloquent dictum was "religion is for God, the fatherland is for everyone." However, during recent decades the Arabic literature that $20^{\text {th }}$-century Iraqi-Jews have produced has been totally relegated to the margins of Arabic culture. This development was due not only to political and national circumstances but also to the aesthetic and cultural norms of both Arabic-Muslim and Hebrew-Jewish cultural systems. The vision embedded in the aforementioned dictum was the product of a very limited period, a very confined space, and a very singular history. It lived to the age of a sturdy human being, by this rare combination of time, space and history, before disappearing and being forgotten, at least for the foreseeable future.

Keywords: Baghdad, Babylon, Arab-Jewish culture, Arabic literature, Hebrew literature, Zionism

The 137th psalm of the Book of Psalms, known as "By the rivers of Babylon," is a communal lament about being in exile after the Babylonian captivity, and yearning for Jerusalem:

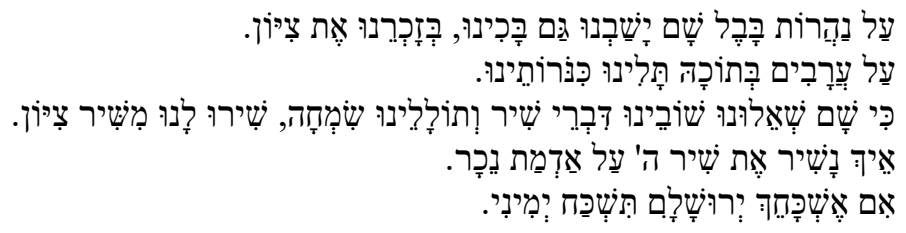




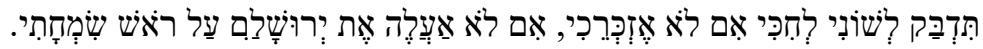

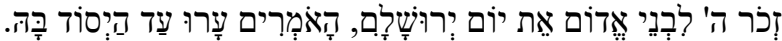

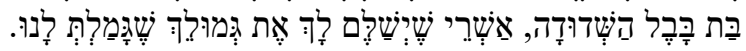

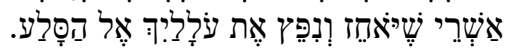

In the King James Version, we find the following translation of the nine verses:

By the rivers of Babylon, there we sat down, yea, we wept, when we remembered Zion.

We hanged our harps upon the willows in the midst thereof.

For there they that carried us away captive required of us a song; and they that wasted us required of us mirth, saying, Sing us one of the songs of Zion.

How shall we sing the LORD's song in a strange land?

If I forget thee, O Jerusalem, let my right hand forget her cunning.

If I do not remember thee, let my tongue cleave to the roof of my mouth; if I prefer not Jerusalem above my chief joy.

Remember, O LORD, the children of Edom in the day of Jerusalem; who said, Rase it, rase it, even to the foundation thereof.

O daughter of Babylon, who art to be destroyed; happy shall he be, that rewardeth thee as thou hast served us.

Happy shall he be, that taketh and dasheth thy little ones against the stones.

The psalm expresses the yearnings of the Jewish people during their Babylonian exile for Jerusalem as well as their hatred for the enemies with violent imagery. The first lines describe the sadness of the Israelites in exile, weeping and hanging their harps on trees. Asked to "sing the Lord's song in a strange land," they refuse. Then the speaker turns to self-exhortation to remember Jerusalem and the psalm ends with prophetic predictions of violent revenge. The psalm is customarily recited on Tish 'a Be' $A v$, the 9th day of the month of Av - the eleventh month of the civil year on the Hebrew calendar. It is the saddest day of the Jewish year, on which Jews fast, deprive themselves and pray, commemorating the destruction of the Temples in Jerusalem. In fact, the psalm originally lamented only the destruction of the First Temple, totally destroyed by the Babylonians in 586 BC, after Nebuchadnezzar II's successful siege of Jerusalem in $597 \mathrm{BC}$. The inhabitants of the Kingdom of Judah were deported to Babylonia, where they were held captive until after the Fall of Babylon in 539 BC. The "rivers of Babylon" mentioned in the lament are the Euphrates and the Tigris rivers - this is the region of Mesopotamia (from the Greek, meaning "between two rivers") located in the eastern Mediterranean and bounded in the northeast by the Zagros Mountains and in the southeast by the 
Arabian Plateau, corresponding mainly to today's Iraq but also parts of modern-day Iran, Syria and Turkey.

The Jews of Mesopotamia spoke Aramaic - the language they used to produce the Talmud, the central text of Rabbinic Judaism and the primary source of Jewish religious law (halakha) and Jewish theology. After the Arab conquest, especially under the Abbasid Caliphate, the then-thriving Jewish community underwent a rapid process of Arabization and integration into the surrounding Arab-Muslim society, the majority of the community congregating in the new metropolis of Baghdad. Even before the Arabization of Iraq, there had been Jewish tribes during the pre-Islamic period in the territories of Hijaz with many Jewish poets who contributed to Arab-Islamic civilization before and after the emergence of Islam. During the 11th - 13th centuries in Muslim Spain (al-Andalus) we even find Jewish authors so at home in fuṣh $\bar{a}$ (standard literary Arabic) that they were able to achieve great recognition for their works. ${ }^{1}$ But since the mid-13th century, Jews were nowhere as open to participation in the wider Arabic culture, and at home in fușha, as from the 1920s in Iraq. ${ }^{2}$ This involvement was encouraged by the process of modernization and secularization of the local Jews since the second half of 19th century. Other Jewish communities in the Middle East and North Africa went through similar processes, but only in Egypt can we also find close involvement in Arabic literature, although it was far less intense than in Iraq.

The present article examines the emergence of the literary writing in Arabic of the Jews of Iraq during the 1920s and, after only a few decades, the start of its demise, in both Iraq and outside it, and then the switch to writing in Hebrew in Israel. I will try to show, that this was due not only to political and national circumstances but also to the aesthetic and cultural norms of both Arabic-Muslim and Hebrew-Jewish cultural systems.

\section{Cultural Background}

After more than 2,500 years, by the 1920s the Jews of Babylon had by no means any sympathy for the aforementioned lament other than its ritualistic function Iraq of most of the first half of the 20th century was considered the perfect homeland for its Jewish community. Having lived in the country without interruption for two millennia and a half and tracing their settling in Iraq back to the Babylonian exile, Iraqi-Jews developed a sort of Andalusian vision of

1 STERN, S. M. Arabic Poems by Spanish-Hebrew Poets, pp. 254-263.

2 On the historical background, see REJWAN, N. The Jews of Iraq, 3000 Years of History and Culture. 
integration in the new Iraqi nation-state. It was a vision that had solid roots in the previous century, especially during the tenure as governor of Midhat Pasha, the leading advocate of Ottoman tanzimat reforms $(1869-1872)$. The foundation in 1864 of the Alliance Israélite Universelle (AIU) school in Baghdad, where education was predominantly secular, played a major role in the modernization of the local community, which became gradually more open to the outside world than the local Christians and Muslims.

Wealthy Jews also used to send their sons to be educated in European institutions, where they were influenced by the atmosphere of the Enlightenment, especially with regard to the advantages which participation in the cultural and social activities of the wider society could offer them. Sasun Hiskīl (Sassoon Yehezkel) (1860 - 1932), for example, did Oriental studies at Vienna where many Jews spoke high German, adopted German names, dressed and acted like Austrians and Germans. In an interview in 1909 with a correspondent of the Hebrew newspaper $\mathrm{Ha}$ - 'Olam (The World), published in Vilna, Sassoon Afandi, at the time one of the representatives of Baghdad in the Ottoman parliament, expressed views inspired by ideas prevalent among European Jews: "Mr. Sassoon wants to be assimilated," wrote Ha-'Olam's correspondent, "and since he does not see any positive aspect which would unite the Jews except religion, he would agree to be assimilated even with the Arabs". ${ }^{3}$ Later, Hiskīl would occupy the post of finance minister in several Iraqi cabinets of the 1920s. Written in an indirect speech - no one would suspect that Sassoon Afandi had used the words "even with the Arabs" - it is an indication that the Ashkenazi-Zionist outlook towards the Arab-Jews was not a phenomenon which developed following the establishment of the state of Israel; it was part of the very essence of Zionism as a national movement inspired by European colonialism. A Jew who was also an Arab did not fit the Zionist venture from its inception - it was guided by what Theodor Herzl (1860 1904), the founder of modern Zionism, wrote in the late 19th century: "We should form there a portion of the rampart of Europe against Asia, an outpost of civilisation as opposed to barbarism."

The Christian Assyrian writer Yūsuf Rizq Allāh Ghunayma (1885 - 1950), who was educated at the AIU school in Baghdad (1898 - 1902), and later became Minister of Finance in one of the Iraqi cabinets, wrote in 1924 that the Jews of Iraq "considered the country as their homeland and the Arab Iraqi

${ }^{3}$ Ha- 'Olam, 10 March 1909 (my emphasis - R. S.).

${ }^{4}$ HERZL, T. The Jewish State: An Attempt at a Modern Solution of the Jewish Question, p. 30. 
government as the government, which they must support". The government was also very responsive to the patriotic sentiments of Jews and to their desire to be an active component of Iraqi society and Arab-Muslim culture. "Every person who speaks Arabic is an Arab," said Sāti‘ al-Huṣrī (1880 - 1968), the Director General of Education in Iraq (1923 - 1927) and Arab nationalism's first true ideologue. ${ }^{6}$ With the aim of making the very mixed population of the new nation-state homogeneous and cohesive, he looked upon schools as the means by which to indoctrinate the young in the tenets of Pan-Arabism, seeking the "assimilation of diverse elements of the population into a homogenous whole tied by the bonds of a specific language, history, and culture to a comprehensive but still exclusive ideology of Arabism". 7 On 18 July 1921, one month before his coronation as the king of Iraq, Amir Fayșal (1883 - 1933) declared before Jewish community leaders that "in the vocabulary of patriotism, there is no such thing as Jew, a Muslim, or a Christian. There is simply one thing called Iraq [...] all of us related to the Semitic root, which makes no distinction between Muslim, Christian or Jew". 8

The government's organized educational efforts to create a specific Iraqi-Arab national community for all religious and ethnic groups fostered national and patriotic awareness among the Jews. Toward the middle of the 1920s, Jewish educational institutions put heavy emphasis on teaching Arabic; the writer Salmān Darwīsh $(1910$ - 1982) wrote that Arabic language and literature had "penetrated our very bloodstream". 9 Arabic became, according to the novelist Ishāa (Isaac) Bār-Moshe (1927 - 2003), a "decisive fact of life". 10 The fluent Arabic style of the Jews was more than once judged superior to that of their non-Jewish counterparts. The Syrian Muslim educator 'Alī al-Ṭantāwī (1906 - 1999) even noted that after the excellence of Jews in Arabic studies had troubled one school administration it was decided to combine instruction in Arabic literature with instruction in Muslim studies. This still did not prevent the Jewish students from excelling in the new curriculum. ${ }^{11}$

${ }^{5}$ GHANIMAH, Yusuf Rizk-Allah. A Nostalgic Trip into the History of the Jews of Iraq, p. 149.

6 CLEVELAND, W. L. The Making of an Arab Nationalist, p. 127.

7 Ibid., p 63.

8 Al- 'irāq, 19 July 1921.

9 DARWĪSH, S. Kull shay' hādi' fi al- 'iyāda [All Is Quiet in the Surgery], p. 200.

10 BĀR-MOSHE, I. Bayt fi baghdād [A House in Baghdad], p. 231.

11 Al-sharq al-awsaț (London), 24 May 1984, p. 10. 
It is thus not surprising that following the 1917 Balfour Declaration, ${ }^{12}$ the British cultural anthropologist Ethel Stefana Drower (née Stevens) (1879 1972) wrote that a Syrian complained to her: "If the Jews want a National Home, why don't they go to Mesopotamia? Their father Abraham was an 'Iraqi, a large part of the race has lived there ever since the captivity, and there are more Jews today in "Iraq than in the whole of Palestine". ${ }^{13}$ In the wake of the First World War the intellectual secular elite of Iraqi-Jews, was rallying behind the efforts to make Iraq a state for all its citizens-Muslims, Christians and Jews. In the late 1930s the educator 'Ezra Haddād (1900 - 1972) declared that "we are Arabs and only after that we are Jews". The poet and short story writer Ya'qūb Balbūl (1920 - 2003) wrote that "a Jewish youth in the Arab countries expects nothing from Zionism except colonialism and domination". 14 Emile Marmorstein (1901 - 1983), headmaster of the Shammāsh school in Baghdad during the 1930s, wrote that the Iraqi-Jews "are attached to their homes, traditions and shrines of the prophets, and would not like to leave them in order to begin once more in an immigrants' camp in Israel, where, they believe people are not particularly friendly to Oriental Jews". ${ }^{15}$ A survey published in 1950 said that except for a natural interest in the developments in Palestine, there has never been in Iraq any feeling of solidarity with the political aspirations of Zionism. ${ }^{16}$ Considering themselves an integral part of Arab-Muslim culture and Iraqi nation, Iraqi-Jews were full of confidence that Iraq was their only homeland, as the writer Shālūm (Shalom) Darwīsh (1913 - 1997) was to put it, "to the days of the Messiah". 17 Examining the aforementioned testimonies, it is impossible to think that those who uttered them would "sit by the rivers of Babylon" and weep remembering Zion.

\footnotetext{
12 The Balfour Declaration was a single paragraph in a letter sent on 2 November 1917 by the British Foreign Secretary Arthur James Balfour $(1848$ - 1930) to Lord Rothschild (1868 - 1937); it stated that "his Majesty's Government view with favour the establishment in Palestine of a national home for the Jewish people".

13 STEVENS, E. E. By the Tigris and Euphrates; quoted in HAIM, S. G. Aspects of Jewish Life in Baghdad under the Monarchy, p. 188.

${ }^{14}$ REJWAN, N. The Jews of Iraq, 3000 Years of History and Culture, p. 219.

15 MARMORSTEIN, E. Baghdad Jewry's Leader Resigns.

16 LANDSHUT, S. Jewish Communities in the Muslim Countries of the Middle East, p. 45.

17 DARWISH, S. Relations Between Communal Institutions and the He-Halutz Underground Movement in Baghdad, p. 83.
} 


\section{The Emergence of Literary Writing in Arabic}

The high point of writing in modern literary Arabic by Jews was only during the 1920s. 10 April 1924 saw the publication of the first issue of the journal Al-mișbăh (The Candlestick) whose owner, editor as well as most writers were Jews. The journal's aim was to contribute to Iraqi-Arab culture with no narrow Jewish agenda at all. This was also the time when Iraqi-Jews started to produce literary works which "were Arabic in essence and expression". ${ }^{18}$ It was a secular literature, inspired by a cultural vision whose most eloquent dictum was al-dīnu li-llāhi wa-l-watanu li-l-jam $\bar{l}^{\prime}$ (religion is for God, the fatherland is for everyone). ${ }^{19}$ Jews wrote in various genres but it was as short story writers that they were to make their most significant contribution to Iraqi literature. They were so well-integrated within the cultural and national enterprise of the new Iraqi state, that their literary works can by no means described as Jewish, except for the ethnic and religious origins of the authors.

One of the first short stories published by an Iraqi-Jew was "Bayna Anyāb al-Bahr" (Between the Fangs of the Sea) ${ }^{20}$ The author used the pseudonym of Fatā Isrā'îl, "Youth of Israel," indicating that through his communal identity he belonged to the wider fabric of Iraq's new society. It was not, of course, expressive of any Jewish nationalist tendency - Zionism was not yet in the picture in Iraq. The story is illustrative of the cultural circumstances surrounding the emergence of the new genre among Jewish writers - they were moving into a territory which was relatively untrodden. It is thus understandable that the influence of popular Arab folk narratives is to be found in their works. For example, very often the role played by the narrator is similar to that of the itinerant storyteller who used to perform in places such as coffee-houses and public squares and retell stories inspired by hoary folk tales and legends. The story also contains elements of the miraculous and the descriptions are generally based on the senses of sight and hearing: the reader can imagine the narrator as if he is standing, at the time of the narration, in front of an audience that is incapable of, or uninterested in, absorbing an intellectual or analytical presentation. Yet, it is not a folk tale: written in fuṣha, it contains the basic elements of the modern short story such as the organization of the action and

18 SHIBLAK, A. The Lure of Zion - The Case of the Iraqi Jews, p. 28.

19 SHĀ'UL, A. Qișșat hayātī fì wādī al-rāfidayn [The Story of My Life in Mesopotamia], pp. 119, 223; DARWĪSH, S. Kull shay' hādi' fì al- 'iyāda [All Is Quiet in the Surgery], p. 202.

20 The story was published in two parts in Al-miṣbāh I,1 (10 April 1924), p. 6; I, 2 (17 April 1924), p. 7. For a translation of the story, see Snir, R. Arab-Jewish Literature: The Birth and Demise of the Arabic Short Story, pp. 204-206. 
interaction of the characters into an artful pattern. Because the main aim is to reach a totality of effect, the principle of selectivity is preserved: it has a plot which has a beginning and develops through a middle into some sort of denouement at the end. "Between the Fangs of the Sea" contained several "seeds" that heralded the next stage, characterized by various elements of the romantic school, which became dominant in Arabic literature in the late 1920s and the 1930s.

One of the Jewish writers who very early started to develop a romantic poetics was Murād Mīkhā'îl (1906 - 1986), who is considered to have been the first Iraqi writer to publish a short story in the Western sense. His "Al-bā'is" (The Unfortunate Man) ${ }^{21}$ echoes in its title and content Victor Hugo's Les Misérables (1862), which had been translated at the start of the 20th century into Arabic under the title Al-bu'as $\bar{a}{ }^{2}{ }^{22}$ The description of nature in the story is used effectively to give the reader an insight into the soul of this unfortunate man. The social aspects of French romanticism in the story come to the fore in the sharp dichotomy between individual and society as well as in the revolt against fate as understood from the clear stance of the narrator and the implied author. Mīkhā'îl's story consistently attempts to escape the influence of popular literature and to integrate modern elements of the art; the style is more polished and avoids the tendency to digress from the main theme. Concentrating on one character, the single episode was carefully selected to reveal as much as possible of the totality of the protagonist's life and character, while details are carefully devised to have maximum significance.

The writings of the aforementioned Anwar Shā'ul who was very active in the literary life of Iraq from the 1920s may illustrate the next stage in the development of the Iraqi short story. He served as the editor of two journals, the aforementioned Al-mișbāh and Al-hạșid (The Reaper), the most influential Iraqi literary journal in the 1930s. Confident that his religion would not pose an obstacle to integration into Iraqi society, in December 1929 he even read out in the al-Kaylani mosque in Baghdad an elegy for the deceased Iraqi leader 'Abd al-Muḥsin al-Sa'dūn $\left(1879\right.$ - 1929). ${ }^{23}$ Shā'ul's major contribution to Iraqi literature was in the field of the short story. In 1930 he published Al-hașād al-awwal (The First Harvest), one of the first collections of short stories in Iraq. In the introduction to the collection, which includes 31 stories, he presents his

21 Al-hadith I, 3 (1928), pp. 98-100. For a translation of the story, see SNIR, R. Arab-Jewish Literature: The Birth and Demise of the Arabic Short Story, pp. 207-208.

22 PÉRÈS, H. Le roman, le conte et la nouvelle dans la littérature arabe moderne, p. 299.

23 SHĀ'UL, A. Qișsat hayātī fì wādì al-rāfidayn [The Story of My Life in Mesopotamia], pp. 119-124. 
firm conviction that literature is a critical medium and a vehicle of social reform. Literature cannot be based on "enthusiastic kisses exchanged by a couple of lovers" - it must have its roots in the customs, traditions, and moral standards of the society, as well as in the shortcomings and the confusions existing in it. ${ }^{24}$ This conception may be illustrated by his story "Banafsaja," 25 which addresses the issue of the status of women in traditional Arab society. The story is about the attractive and charming Banafsaja who falls in love with a young man but the family intends to betroth her against her will to a wealthy man who is over forty years old, whereas she is only nineteen. The core of the story is an ironic scene in which members of her family are gathering to decide her fate, without her presence. The engagement was planned for the day after the gathering but the girl decides to fight back - she is not "an item of merchandise to be bought and sold in the marketplace." The chief purpose of the author was to convey the social message of improving women's status and extending to them equal rights, including access to education, the first area in which women gradually began making significant gains.

\section{Emigration and the Clash of Narratives}

As a result of the escalation of the conflict in the Middle East, religious and national identification became blurred and the distinctions made by early Arab nationalists between Jewish religion and political Zionism gradually disappeared. The definition of Arabism became ever narrower and excluded Jews; because of Palestine no matter how vociferous was their loyalty as Iraqi-Arabs and how much they denied Zionist partisanship, Jews became targets of anti-Zionism and anti-Semitism. The Farh $\bar{u} d$ in Baghdad in June 1941, when more than one hundred and fifty Jews were killed and Jewish property was looted, led to an obfuscation of the Jews' role in Iraqi society by instilling doubts about their loyalty. Jewish young men were pressed into joining the Zionist movement or the Communist underground. While the former joined the struggle for the establishment of an independent Jewish state, the later fought against a corrupt regime and for equal rights for all minorities.

Following the establishment of Israel many Iraqi-Jewish poets and writers emigrated to the new state, while a much smaller number decided to seek their fortune in the West. One of them is Naïm Kattan (b. 1928), who left Baghdad

\footnotetext{
24 SHĀ'UL, A. Al-ḥașād al-awwal [The First Harvest], p. 6.

25 SHĀ'UL, A. Al-hașād al-awwal [The First Harvest], p. 9-13. For a translation of the story, see SNIR, R. Arab-Jewish Literature: The Birth and Demise of the Arabic Short Story, pp. 209-211.
} 
for Paris and then for Canada. Kattan published an autobiographical novel on his life in Iraq entitled Adieu, Babylone. ${ }^{26}$ Only a few chose to stay in Iraq. The writers who opted for Israel faced harsh material conditions and the difficulties of adapting to the new society. Since the 1960s, most Iraqi-Jewish writers and poets have gradually severed themselves from any creative activities. The very few who insisted on remaining true to their cultural origins and continued to write in Arabic were soon faced with a language dilemma: their mother tongue was Arabic but now it is the language of the enemy; the language of the new state is Hebrew, the language of Zionism. Among them was Samīr Naqqāsh (1938 - 2004) whose words, some years before his death, illustrated his isolation: "I don't exist in this country [Israel], not as a writer, a citizen nor human being. I don't feel that I belong anywhere, not since my roots were torn from the ground [in Iraq]". ${ }^{27}$

The gradual demise of Arabic literature among Jews has precipitated a new controversy regarding the cultural preferences of Western-oriented Israeli society. The dilemma was whether Arab culture could be considered a "correct" source of inspiration for the new Israeli culture. Sooner or later Iraqi-Jewish writers who emigrated to Israel were confronted with the stark choice of which language they should write in and communicate via, that is, whether to continue to write in Arabic or to adapt to their new cultural surroundings and make the required shift in their aesthetic preference and start writing in Hebrew, in the hope of finding a new audience.

\section{The Shift to Writing in Hebrew}

The writers who succeeded in adapting to writing in Hebrew gradually adopted the poetics of Hebrew literature and most of them accepted the Zionist narrative as well, while still insisting on retaining various degrees of belonging to Arab culture. The fact that they have been writing for a Hebrew audience, most of whom have a strong preference for Western culture, has dictated to some extent a change in their poetic conceptions and brought about a change in their literary preferences. Shimon Ballas $(1930$ - 2019) was one of the first who, while adapting to writing in Hebrew, has tried to adhere to his original cultural preferences as "an Arab Jew". Explaining his switch to Hebrew, Ballas says that he felt that in Arabic he was isolating himself from the society in which he was

\footnotetext{
26 KATTAN, N. Adieu, Babylone.

27 BERG, N. E. Exile from Exile - Israeli Writers from Iraq, p. 3.
} 
living. However, "this does not mean, however, that I have given up my cultural origins, and my cultural origins are Arab". ${ }^{28}$

Born in the Christian quarter of Baghdad (al-Dahāna), Ballas came to adopt a secular cosmopolitan world view. He was educated at the AIU school where he mastered Arabic and French, the latter serving as his window on world literature. The fact of his immigration to Israel in 1951 was by no means motivated by any Zionist preferences; his experience in ma'abarah - an immigrant transit camp - and his activities in the Communist party inspired his literary production. He served for six years as editor of Arab Affairs for the Communist Party's Hebrew organ, Kol Ha 'am (The Voice of the People) and published Arabic short stories and essays. After leaving the party in 1961, Ballas has since devoted himself to literary writing, academic research and translation. His first novel was originally completed in Arabic and entitled Mudhakkirāt Khādima (Memories of a Maid) but before publishing it he decided to switch over to writing in Hebrew. He rewrote the novel in Hebrew and published it in 1964 as Ha-Ma 'abarah (The Immigrant Transit Camp), the first Hebrew novel by an Iraqi émigré. The novel depicts the tragedy of the Arab-Jewish immigrants who were uprooted from their homes and reduced to poverty and thrown back on insufficient resources. Ballas' approach, however, was to skirt the material deprivation of the new immigrants and focus on their cultural impoverishment after their most treasured moral and cultural values were rejected. Thrown into a hostile environment, which felt contempt for their original culture, they were labelled as exceptional, thus becoming victims of an organized and institutionalized process of adaptation to a culture in which Arabic language, literature, and music were considered inferior and "weapons" of the enemy. Surprisingly, his novel was very well received by critics, some of whom even praised Ballas as representing those Arab-Jews who had preserved Hebrew throughout the generations - even though he, like most Iraqi immigrants, had arrived in Israel knowing no Hebrew at all.

Experiencing alienation and estrangement, most of Ballas' protagonists - or rather, anti-heroes - are outsiders living on the margins of society and unwilling to compromise their principles. Preaching a new connection between identity, language and territory, Ballas demystifies Hebrew, attempting to "un-Jew" it divorce it from Jewishness in a process of "deterritorialization" and "reterritorialization". ${ }^{29}$ The Zionist master narrative, in his view, is an Ashkenazi-Western ideology that developed in a different cultural milieu and came to stake its claim in the Middle East without embracing the Middle Eastern environment. Zionism, according to Ballas, is based on the European

${ }^{28}$ New Outlook, November - December 1991, pp. 30-32.

29 DELEUZE, G. and GUATTARI, F. What is a Minor Literature, pp. 59-69. 
colonialist conception of the Arab East and "the attitude towards the Jews from Arab countries, the Arab-Jews, was no different from the attitude towards the Arabs". ${ }^{30}$ Ever since the mid-1960s, Ballas has boldly challenged the Ashkenazi and Western-oriented reluctance to accept the legitimacy of Arab culture in the Hebrew literary canon. According to Ballas, only after redrawing the new boundaries for Hebrew literature so as to encompass not only cosmopolitan and humanistic values but Arab values as well, will Israeli society be able to boast an original culture in which are expressed the aspirations of its entire citizenry: Jewish, Muslim, and Christian.

Besides Ballas, other Iraqi writers who succeeded in adapting to writing in Hebrew adopted the Zionist narrative in their literary writings, the most prominent of them being the aforementioned Sami Michael. Born in Baghdad in 1926 to a traditionalist family, at the outbreak of the Second World War Michael became involved in a leftist underground group acting against the Iraqi regime and then joined the local Communist Party. After he was sentenced to death, he fled in 1948 to Iran and then emigrated to Israel, joined the Communist Party and worked on the editorial staff of its Arabic weekly organ al-Ittihâd. His writings had a strong social awareness of the gap between the various classes in the new society and emphasized the necessity to improve the conditions of the proletarian masses. His story "Abbās" 31 for example, describes the role of the Communist party in society and the suffering of its members as they sacrifice themselves for the collective well-being. In the early 1950s, when he was still publishing only in Arabic, Michael tried his hand at Hebrew: he started to write a novel that took place in a ma'abara, that is, an immigrant transit camp. In 1954, he published a chapter of a novel, entitled "Harīq" (Fire), but only in Arabic translation. ${ }^{32}$ In the late 1950s, Michael ceased publishing in Arabic; approximately at the same time he left the party; it was the first step in a long process of adapting himself to the mainstream of Israeli culture. He joined the Israel Hydrology Service in the Ministry of Agriculture, where he worked for 25 years surveying water sources, mainly on the Syrian border. Ending his literary silence, the first novel he published was a Hebrew one, Shavim Ve-Shavim Yoter ([All Men Are] Equal, but Some Are More) (1974) whose nucleus was the above-mentioned Hebrew text he wrote in the 1950s. It exposed the humiliating attitude of the authorities to the

\footnotetext{
${ }^{30}$ Ha'aretz, 4 July 2003, p. 50.

31 Al-jadì, February 1955 , pp. 24-29.

32 Al-jadìd, December 1954, pp. 39-43. Later Michael revealed that he had completed this Hebrew novel, entitling it Ge'üt ha-Nahal [The Rise of the Stream], and that he had tried to publish it with Am Oved, one of Israel's leading publishing houses at the time, but it had been rejected (Ha'aretz [Books - Special Issue], 17 October 2005).
} 
Arab-Jewish immigrants and raised a storm of protest bringing to the fore the ethnic question, especially by introducing the motif of the DDT spray with which the immigrants were disinfected; it was immediately adopted as a symbol of their humiliation in Israeli society.

In his subsequent novels Michael continued to deal with the margins of Israeli society. It was, however, the publication of his bestselling novel Victoria (1993) that established Michael as a well-known writer. The novel soared to the top of the Israeli best-seller list, selling around 100,000 copies; for 50 weeks it stayed at the top of the list of the Ha'aretz newspaper's weekly books supplement. It was translated into English, Dutch, German, Greek, Arabic and French. Named after its female heroine who, as her name suggests, succeeds in overcoming the challenges of her life, the novel describes the life of Iraqi-Jews before and after their emigration. It was argued that the accent in which Michael wrote this novel is that of the margins, a minority accent, even while entering the mainstream. Critics described it as exotic, fantastic, and sensational with a plot flavoured with elements of A Thousand and One Nights; it was classified with Flaubert's Madame Bovary and Tolstoy's Anna Karenina.

The great gap between Michael's writings in Arabic in the 1950s and his writings in Hebrew since the 1970s may illustrate the metamorphosis the author had undergone from being an Arab-Jew adhering to Communism, to the adoption of the Zionist master narrative. Whereas the description of conditions in Iraq in Victoria might otherwise be thought of as an attempt to enter the popular world of sensationalism, in retrospect with the last chapter the entire book takes on a new meaning: the Ashkenazi Zionist dream came true through the description of a sparkling clean home.

\section{Conclusion}

The Arabization of the Jewish intellectual elite in Iraq during the first half of the 20th century was so intense that it recalls the Arabization of the Jews in al-Andalus, where they had been speaking Arabic for generations and "came to think in and view the world through the medium of that language". ${ }^{33}$ Likewise, the Iraqi-Jewish secular intellectuals felt that the Arabic language, which they had been speaking for generations, was a kind of "an arsenal, a vocabulary, a system of signs," as Jean Sulivan put it, "that permits the individual to be part of the tribe". ${ }^{34}$ The choice made by them to write and publish in Arabic was primarily motivated by inner aesthetic Arabic cultural preferences. In the 1920s

33 BRANN, R. The Arabized Jews, p. 441.

34 SULIVAN, J. Minor Writers / Authentic Words, p. 59. 
and the 1930s Baghdad represented a rare opportunity for a "new" Middle East where nationalist ideologies would have given way to cultural cooperation and religious tolerance. However, after 1948, the Arabic literature 20th-century Iraqi-Jews produced has been entirely relegated to the margins of Arabic culture. Like the spirit of Alexandrian cosmopolitanism, the demise of which was somehow predictable, the vision embedded in the aforementioned dictum, "religion is for God, the fatherland is for everyone," was the product of a very limited period (mainly the 1920s and the 1930s), a very confined space (specifically Baghdad), and a very singular history (that of the crumbling Ottoman empire and prior to the increasing power of Zionism). It became ripe by these rare combination of time, space and history, before disappearing and forgotten, at least for the foreseeable future.

The documentary film Forget Baghdad: Jews and Arabs - The Iraqi Connection (produced by Dschoint Ventschr, Zurich, 2002) directed by the Iraqi Shiite exile filmmaker Samīr Jamāl al-Dīn (b. 1955) epitomizes the demise of Arab-Jewish identity and culture. The film revolves around the life of five Iraqi Arabized Jews: Mūsa Ḥūrī (1924 - 2010), Sami Michael (b. 1926), Shimon Ballas (1930 - 2019), Samīr Naqqāsh (1938 - 2004), and Ella Shohat (b. 1959). ${ }^{35}$ Except for their common ethnic origins, they hardly have anything in common. The differences between these common layers of identity that all of the aforementioned intellectuals and authors share, such as Iraqiness and Arabness, are more significant than the differences between the layers of identity such as Israeliness and Hebrewness that they share with their non-Arabized Israeli-Jewish counterparts. For example, what Naqqāsh considered as true basic Arab cultural characteristics is totally different of what seen by Shohat as such characteristics - in fact, she does not master Arabic! On the other hand, if we compare most of Sami Michael's recent Hebrew novels with most contemporary Hebrew novels by any leftist writer of his generation, it will probably be hard to find essential differences between their literary, cultural, and ideological narratives ${ }^{36}$ Furthermore, the corpus of Arab belles lettres written by Jews during the 20th century has hardly become wider during the last two decades. Jews do not now write Arabic literature and if they do so at all their works are not published; no one is interested in such writing anymore. For the last 35 years I have been closely investigating the whole corpus of Arab-Jewish poems, stories, novels, plays, and memoirs written in Iraq and Israel since the 1920s. The hidden voice of the implied collective author of these works

35 On the film, see TSOFFAR, R. Forget Baghdad: Roundtrip to the Promised Land, pp. 133-143.

36 On the issue of Arab-Jewish identity and other layers of identity, see SNIR, R. Who Needs Arab-Jewish Identity? Interpellation, Exclusion, and Inessential Solidarities. 
written after the immigration of the Iraqi Jews to Israel is a sad lament, inspired by but at the same time contradicting the 137th psalm quoted earlier and may be summarized in the following lament:

By the rivers of Zion, there we sat down, yea, we wept, when we remembered Babylon.

We hanged our harps upon the willows in the midst thereof.

If I forget thee, O Baghdad, let my right hand forget her cunning.

\section{REFERENCES}

BĀR-MOSHE, Isḥāq. Bayt fi baghdād [A House in Baghdad]. Jerusalem: Rābițat al-Jāmi 'iyyīn al-Yahūd al-Nāziḥin min al-'Irāq, 1983.

BERG, Nancy E. Exile from Exile - Israeli Writers from Iraq. Albany: State University of New York Press, 1996.

BRANN, Ross. The Arabized Jews. In MENOCAL, M. R. et al. (eds.). The Cambridge History of Arabic Literature: The Literature of al-Andalus. Cambridge: Cambridge University Press, 2000. pp. 435-454.

CLEVELAND, William L. The Making of an Arab Nationalist: Ottomanism and Arabism in the Life and Thought of Sati' al-Husri. Princeton, N. J.: Princeton University Press, 1971.

DARWĪSH, Salmān. Kull shay' hādi' fi al- 'iyāda [All Is Quiet in the Surgery]. Jerusalem: Rābițat al-Jāmi‘iyyīn al-Yahūd al-Nāziḥ̄n min al-'Irāq, 1981.

DARWISH, Shalom. Ha-yahasīm bein mosadot ha-kehila le-bein ha-mahteret ha-halutzit be-baghdad [Relations Between Communal Institutions and the He-Halutz Underground Movement in Baghdad]. In YEHUDA, Zvi (ed.). From Babylon to Jerusalem, ed. Zvi Yehuda. Tel Aviv: Iraqi Jews' Traditional Cultural Center, 1980. pp. 82-85.

DELEUZE, Gilles and GUATTARI, Félix. What is a Minor Literature? In RUSSELL Ferguson (eds.) et al. Out There: Marginalization and Contemporary Cultures. New York \& Cambridge, MA: New Museum of Contemporary Art; MIT Press, 1990. pp. 59-69.

GHANIMAH, Yusuf Rizk-Allah. A Nostalgic Trip into the History of the Jews of Iraq (trans. A. Dallal). Lanham \& New York \& Oxford, 1998.

HAIM, S. G. Aspects of Jewish Life in Baghdad under the Monarchy. In Middle Eastern Studies 1976, Vol. 12, No. 2, pp. 188-208.

HERZL, Theodor. The Jewish State: An Attempt at a Modern Solution of the Jewish Question (trans. D'AVIGDOR, S). London: Central Office of the Zionist Organization, 1936. 
KATTAN, Naïm. Adieu, Babylone. Montréal: Julliard, 1975.

LANDSHUT, S. Jewish Communities in the Muslim Countries of the Middle East. London: The Jewish Chronicle, 1950.

MARMORSTEIN, Emile. Baghdad Jewry's Leader Resigns. In The Jewish Chronicle, 30 December 1949.

PÉRÈS, Henri. Le roman, le conte et la nouvelle dans la littérature arabe moderne. In Annales de l'Institut d'Études Orientales, 1937, Vol. 3, pp. 266-337.

REJWAN, Nissim. The Jews of Iraq, 3000 Years of History and Culture. London: Weidenfeld \& Nicholson, 1985.

SHĀ'UL, Anwar. Al-hasāād al-awwal [The First Harvest]. Baghdad: Maṭba'at al-Jam'iyya al-Khayriyya, 1930.

SHĀ'UL, Anwar. Qișsat hayātī fì wādī al-rāfidayn [The Story of My Life in Mesopotamia]. Jerusalem: Rābițat al-Jāmi ‘iyyīn al-Yahūd al-Nāziḥīn min al-'Irāq, 1980.

SHIBLAK, Abbas. The Lure of Zion - The Case of the Iraqi Jews. London: Al Saqi Books, 1986.

SNIR, Reuven. Who Needs Arab-Jewish Identity? Interpellation, Exclusion, and Inessential Solidarities. Leiden: Brill, 2015.

SNIR, Reuven. Arab-Jewish Literature: The Birth and Demise of the Arabic Short Story (With an Anthology of 16 Translated Short Stories by Arabized Jews). Leiden: Brill, 2019.

STERN, S. M. Arabic Poems by Spanish-Hebrew Poets. In LAZAR, M. (ed.). Romanica et Occidentalia Etudes dédiées à la mémoire de Hiram Peri (Pflaum). Jerusalem: Magnes Press, 1963. pp. 254-263.

STEVENS, E. E. By the Tigris and Euphrates. London: Hurst and Blackett, 1923.

SULIVAN, Jean. Minor Writers / Authentic Words. In Religion \& Literature 1994, Vol. 26, No. 3, pp. 59-79. Available from https://www.jstor.org/stable/ 40059595?seq=1.

TSOFFAR, Ruth. Forget Baghdad: Roundtrip to the Promised Land. In Anthropological Quarterly, 2006, Vol 79, No. 1, pp. 133-143. Available from https://muse.jhu.edu/article/194833 . 